\title{
Learning to weave; weaving to learn ... what?
}

\author{
Soumhy Venkatesan University of Manchester
}

\begin{abstract}
This paper places the anthropology of learning in conversation with the anthropology of work by unpacking the interrelationship between the processes by which a skill is learned and knowledge about the skill, its possibilities and ramifications. The paper's ethnographic focus is the Labbai mat-weavers of Pattamadai town in South India, who are ambivalent about being weavers. It contrasts this ambivalence with the excitement that weaving generated in a development practitioner who sought to promote the weaving industry and who also learned how to weave. The same skill is approached differently by different kinds of persons: they understand and learn different things. Learning and knowing cannot be easily separated. By focusing on the various purposes and modes of learning, on the social production of knowledge, and on instances of communication and miscommunication, the paper explores the embodied and historicized production of knowledge by different kinds of person: the mat-weavers, the development professional, and, to a certain extent, an anthropologist.
\end{abstract}

This paper investigates two related questions, both of which stem from the larger project driving this special volume: the investigation of processes that define learning, thinking, and practice. My own material focuses on the embodied skill of weaving; in particular, the weaving of mats on hand looms in South India. Firstly, I am interested in the relationship between knowledge of and about weaving as a particular kind of activity, and action pertaining to this knowledge. Secondly, I explore how people learn how to weave, what they know about weaving prior to learning how to weave, and how this knowledge affects their ideas about what it is to weave or to be a weaver.

My main argument is that the acquisition of a skill is embedded in larger social knowledge about the value of the skill based on ideas about the body, gender, identity, politics, and economics. Acquiring, utilizing, or depending upon a skill positions individuals or groups in particular ways, not necessarily of their choosing. Just as gender, marital status, or one's position in a hierarchical order can influence what one can do socially, the things one can or does do (weave, cook, give birth) can locate a person or group by gendering, classing, or categorizing them. Therefore an interesting set of related questions is: what does learning a skill equip one to do, and does one want to do this in light of what and how one learns? In other words, what else is learned alongside the learning of a skill? 
The above is closely intertwined with the question of identity and with the positive or negative identification with particular kinds of work, in this case the work of weaving. For Sandra Wallman (1979: 1-2), work is as much about social transactions as it is about material production. Work controls the identity as well as the economy of the worker. It is more and less than an economic activity. For the worker, work is a personal experience, her relation to the reality in which she lives. However, this personal experience is constrained by the logic of the system within which the person works. Thus, any analysis of work has to ask which forms of work in a given setting are thought to be socially or morally worthy and physically, spiritually, or intellectually fulfilling.

The account that follows focuses on two very different kinds of people: the Labbai Muslims of Pattamadai town in South India, who claim the weaving of high-quality mats as their 'traditional work' (paramparai thozhil), and 'Lila', a development practitioner employed by an NGO set up to develop traditional Indian craft. Lila is committed to the promotion of the mat-weaving industry and, relatedly, to enabling members of the group to continue making mats rather than give it up for other occupations. This involves helping weavers to overcome real and perceived problems with mat-weaving.

Lila, like the Labbais of Pattamadai, also learned how to weave. In exploring how and why she learned to weave and contrasting that with the ways in which the Labbais of Pattamadai arrive at the same skill, I suggest that embedded apprentice-style learning leads to a different kind of knowledge about weaving as compared to independent problem-solving styles of learning. Both modes of learning might lead to what Sennett (2008) terms 'material consciousness', that is, a sensitivity to, knowledge of, and ability to transform materials through tools and skill. But what each kind of practitioner knows about the work and worth of the skill may well be very different - each beginning and ending up with what might be termed a different consciousness of worth. Learning and knowing, then, cannot easily be separated, and, likewise, neither can the anthropology of learning and the anthropology of work.

\section{Preservation, promotion, and development}

Pattamadai is a small town in Tamilnadu state, South India. It has a population of around 13,000 people; the town's Labbai Muslim group numbers about 650. Since the end of the nineteenth century the Labbai Muslims of Pattamadai have been weaving very fine mats on hand looms using locally growing korai (a kind of sedge) as weft on a cotton warp. Korai mats are commonly woven throughout Tamilnadu and are used for a variety of purposes, including seating, bedding, and packing material. Pattamadai mats, however, are distinctive because of the time and skill required in their manufacture and for their resultant silk-like texture. Since 1953, when a Pattamadai mat was commissioned as a coronation gift for Queen Elizabeth II and was seen by the head of the All-India Handicrafts Board (see Nambiar 1964; Venkatesan 2009a; 2009b), the governments of both India and Tamilnadu state have taken an interest in the mats and in the mat-weavers, the former being identified as a traditional Indian craft and the latter as traditional Indian craft producers. A number of non-governmental organizations have also worked with Pattamadai weavers and traders.

The main aim of governmental and non-governmental development interventions is to ensure that Pattamadai mats continue to be made: this is considered important both for the sakes of the weavers, who would otherwise lose their livelihoods, and for the sake of the nation, which would otherwise lose a valuable element of its material and cultural heritage. Governmental support has included, among other things, the commission of 
mats for use in state gifting, invitations to weavers to attend specialist craft bazaars, and the bestowal of national awards for master-craft producers to three mat-weavers, two of whom were subsequently funded to train young people in the craft.

Non-governmental support has tended to focus more on markets and on product development. A Pattamadai mat of the highest quality can take up to a month to weave; this is reflected in its price. Furthermore, the silk-like texture of the mats makes them unfit for the normal uses to which mats are put in Tamilnadu (objects on which people sit or lie down). Weavers do not use the mats they weave, nor has there ever been a customary market for these objects (as reported by Pate 1917; Rao 1929). They are luxury goods for which demand needs to be created. NGOs such as the Madras Craft Foundation and the Crafts Council of India have liaised with government or worked on their own initiative to develop markets for the mats. Working as they mainly do with local Labbai mat-traders to whom weavers sell their mats (see Venkatesan 2006), few of the NGOs based in Pattamadai have much contact with weavers. The exception is one NGO that I will call here Craft Enterprises.

Craft Enterprises was a small NGO with an ambitious brief: to revitalize rural crafts and communities centred on craft production. The NGO, which existed from 1996 to 2001, when its funding ceased, worked with four artisanal groups in South India, including the Pattamadai mat-weavers. Central to Craft Enterprises' work was the presence of a 'facilitator', who would live with the craft group for the first year and build deep relationships with producers and acquire knowledge of their work. In this sense, Craft Enterprises was unusual among the other craft development agencies that worked with Pattamadai mats and weavers, but which had no real presence in the town. The Pattamadai facilitator, Lila, was, in some ways, like me, an anthropologist, living among the people with whom she worked. Unlike me, however, she had a very specific brief to promote and develop the mat-weaving industry. She and I became friends, bouncing ideas off one another and, for a while, sharing the house she was renting in Pattamadai after I arrived to begin fieldwork. ${ }^{1}$

Like other development agencies that have worked in Pattamadai, Craft Enterprises felt that establishing regular markets for the mats would be the most useful step. The NGO's strategy was to buy up 'super-fine mats' or mats of the highest quality (which local traders found difficult to sell and consequently weavers rarely wove) and then sell them in specialist craft exhibitions. ${ }^{2}$ By 1996 Craft Enterprises was regularly buying super-fine mats from traders and, in November 1996, was able to sell them at a craft sale for what were perceived in Pattamadai as very high prices ( $\mathfrak{E}_{30}-\mathfrak{E}_{50}$ per mat). The profits were used as working capital to buy more mats. In early 1997 some weavers of super-fine mats felt confident enough about the NGO's performance to request that the NGO buy mats directly from them rather than from traders. Lila then began to work directly and closely with eight weavers, ${ }^{3}$ commissioning super-fine mats from them, collaborating on designs, holding regular sales in Indian cities, and ploughing the profits back into buying more mats. As a trader, the NGO was extremely effective. Weavers were paid good prices for their mats. ${ }^{4}$ Every mat made by a weaver who worked with Craft Enterprises was bought by the NGO as soon as it came off the loom. Payments were made promptly. The weavers who worked with Craft Enterprises spoke exultantly of having escaped the 'exploitative practices of the local mat traders' (see Venkatesan 2006). Confidence in the future of super-fine mats, which had been on the wane, started to grow. Indeed, some of the weavers who began to work regularly with Craft Enterprises stopped weaving medium-quality (or fine) mats and switched to 
weaving super-fine mats exclusively. Enthusiasm, too, was high, and Lila would spend hours in weavers' homes working out new colour-ways and patterns. The NGO had clearly and successfully entered into a rhythm with the weavers of buying mats off the loom, thereby encouraging new mats to go on looms. The number of weavers regularly weaving super-fine mats was higher than it had ever been, and around eighty super-fine mats a year were being produced for Craft Enterprises.

\section{Innovation and improvement}

Once it looked like Craft Enterprises had managed to stabilize the production and sale of super-fine mats, Lila decided that she wanted to tackle problems with the matweaving loom, since, as she noted in her 1998 project report, 'after a few years of weaving, everyone complains of back, eye and knee problems'. She consulted the weavers about her plans to 'improve' the loom, but 'they insisted on a more "productive" loom for higher output rather than rectifying the physical discomfort due to bad posture forced by the loom'.

Despite the weavers' lack of interest in a loom that would promote better posture, Lila pressed ahead with the project with the support of Craft Enterprises. Her project report noted that a 'brief has been formulated to design a more ergonomic loom which would allow the weaver to stand and weave within a $2 \mathrm{ft}$ range thereby reducing the strain on the back, shoulders and eyes'.

Lila's first attempt to design an improved loom took the form of a collaboration between herself, an ergonomics expert, and a couple of weavers. The ergonomics expert spent two days in Pattamadai along with a yoga practitioner. They took videos of people weaving, spoke to a cloth-weaver in Pattamadai, and studied the cloth loom. In December 1998 the resulting loom was installed in Pattamadai and tested for two months. The weavers, however, were not enthusiastic: the prototype was expensive, large, and too different from what they were accustomed to. Lila decided to try again, reporting in 1999 as follows:

\footnotetext{
We studied the new loom [which had not met with success] and the traditional loom and evolved a holistic guideline for designing the next model - upright sitting posture for comfortable weaving; details of structure to be simplified for manufacturing locally; should fit into existing spaces and conditions; should use existing practices in processes related to weaving such as warping and packing.
}

In addition to studying the loom that weavers used and the new loom that she had collaboratively designed with the ergonomics expert, Lila decided that she needed to master the entire weaving process - from setting up a loom to laying a warp to weaving and finishing a mat. Otherwise, she would not be able to grasp the problems with the existing loom; she would also not be able to design a viable alternative effectively.

Lila had by then spent a year living in Pattamadai and several years making short trips and, being technically proficient and very interested, had grasped the rudiments of weaving. She now decided to dedicate her time to constructing a loom of the kind used by the mat-weavers. In Bangalore, where she lived at the time, she constructed a scaled-down model of the loom, which she referred to as her 'toy loom'. She successfully wove a tiny 4 inch $\times 9$ inch mat on this. While this miniature mat was much appreciated when Lila took it back to Pattamadai, the small loom was also of technical significance. It could be used to try out different warping configurations without going through the protracted task of laying out a warp on the full-size loom. The laying of the warp with 
even tension throughout is one of the most crucial aspects of not just fine and superfine mat-weaving but of weaving in general.

Lila then designed a loom based on what she learned from her experience of constructing the 'toy loom', weaving on it and experimenting with warp configurations. Abdul, a weaver closely associated with Craft Enterprises, offered the yard in front of his house, and the newly designed loom was set up there in early 2000. Loom trials were carried out in the last fortnight of January 2000. Weavers who came forward to try the loom were to be compensated for their time with cash payments. While the loom trials were open to anyone who was interested, Lila strongly encouraged weavers closely associated with Craft Enterprises to come at fixed times and work on the loom. The mood seemed positive at the meeting where all this was decided. But even though weavers, especially those close to Lila, did stick to the trials timetable, they did not at all seem convinced about the need to design a new loom.

In Pattamadai in January 2001 I saw the new loom folded up in a corner of the veranda of Abdul's house, where it had been tested a year earlier. I asked him what he thought about it and received a non-committal answer: 'It is okay, but not suitable' (paravaaillai, aanaal othuvarallai). Today the loom continues to sit unused in a corner at another location.

\section{Suitability and comfort}

Lila, in trying to make a more comfortable loom, sought to enable people to work longer hours, thereby producing more. But comfort is a relative concept. Following Bourdieu, Wilk suggests that when standards are taken for granted, people operate on unspoken shared understanding and physical perception. This includes the concept of 'comfort' (Wilk 2001: 115). Wilk identifies this as naturalization. Submersive naturalization is deeply embedded in bodily practice and habit, profoundly shaping the 'sense of the possibility of any new tool' (2001: 115). Submersive naturalization is not passive, though it may appear so. People actively choose what they are accustomed to, feel comfortable with, and find suits their needs. Lila's loom was a technical masterpiece in some respects, but in others it simply did not suit the requirements of Pattamadai fine mat-weaving.

Weavers value symmetry within a mat with regard to its body, borders, and patterns. This is a strong aesthetic preference. On the extant loom, the mat is laid out fully for the weaver's inspection through every stage of its making. The weaver sits on a low stool placed underneath the warp (Fig. 1). As one section is woven, the stool is moved under it and the weaver sits on the newly woven section in order to continue weaving the next bit. When approximately 9 inches are woven, the weaver gets off the stool, crouches by the mat, and, placing one knuckled fist under and the other over the mat, starts to push the weft strands together. She thereby compacts the mat, making the fabric as tight as she can. The 9 inches are compacted down to around 5 inches. Once this is done, weaving is resumed, interrupted with periodic breaks to compact the fabric. Once the whole mat is woven, the weaver compacts it again, this time paying special attention to the borders and to any patterns. It is possible through careful compacting to correct any discrepancies between the widths of the different coloured border stripes, to ensure that the pattern emerges clearly, and even to rectify mistakes. Compacting is an extremely difficult task and is usually left to more experienced weavers as it is possible to damage the fabric or fail to achieve a sufficiently tight structure. The final compacting of a mat before cutting it off the loom is a crucial task, and less skilled weavers will 


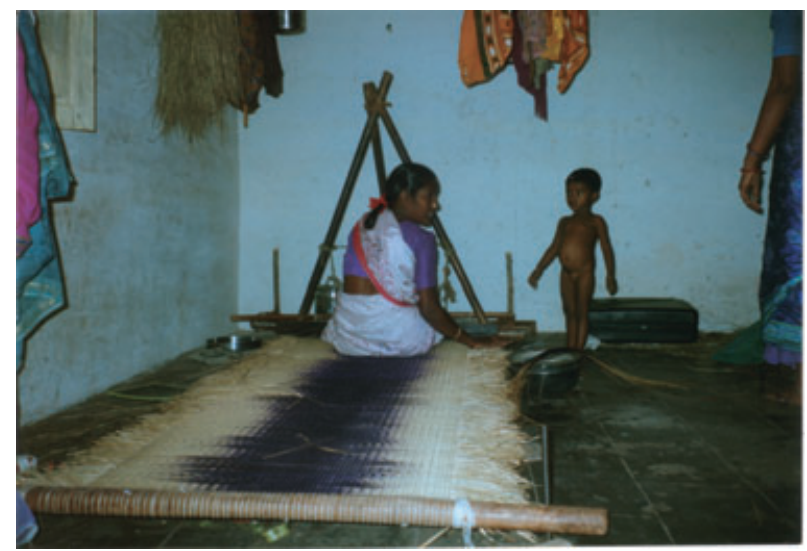

Figure 1. Regina works on a nearly completed mat.

often request more skilled ones to help. It is possible for an experienced person to ensure symmetry by making minute adjustments in packing.

One chief difference between the loom already in use in Pattamadai and Lila's loom is the height of the latter. Designed as a loom for a weaver to sit at on a bench (instead of on a low stool placed directly under the warp and just before the section to be woven), the new loom imposes certain changes in the layout of the mat as it is being woven (Fig. 2). Instead of the entire warp being laid out in front of the weaver so that the whole mat and its skeleton prior to weaving are visible, the warp in the modified loom is rolled up underneath the loom at the end furthest from the weaver. After the weaver weaves and packs a section of the mat, s/he rolls up the finished section underneath the warp. As the mat progresses, the rolled-up warp gradually unfolds before the weaver, is woven, compacted, and rolled up again.

On the loom commonly in use in Pattamadai, it is important to note that the weaver travels the length of the mat as s/he weaves it. At no stage in the weaving process is any part of the mat hidden from the weaver's or anyone else's eyes. This facilitates the general concern to ensure symmetry in border widths and patterning. The desire for symmetry is difficult to satisfy on Lila's loom. The weaver has to pay greater attention to the exact number of weft strands in different colours used throughout the mat, something that practitioners tend to measure with their eyes. In a household with many members, no single person monopolizes the loom. Should the person on the loom get up to attend to some task, someone else might move onto the loom and carry on weaving. The fact that the entire mat (the woven and yet-to-be woven sections) is visible to everyone considerably aids this way of working.

Even in households where weaving provides the main source of income, people spend a few hours on the loom and intersperse weaving with other activities. People sometimes take days off weaving if there is a marriage in the house or some other opportunity presents itself, or if they can afford it. In these instances, the loom is rolled up and put away, even with a half-done mat on it. Because of the whole new component of height on Lila's modified loom, it is not possible to roll it up and put it away in order to acquire more space.

Furthermore, the extant loom requires little financial investment. Most of its components are found to hand or quickly and cheaply fashioned by local carpenters. 


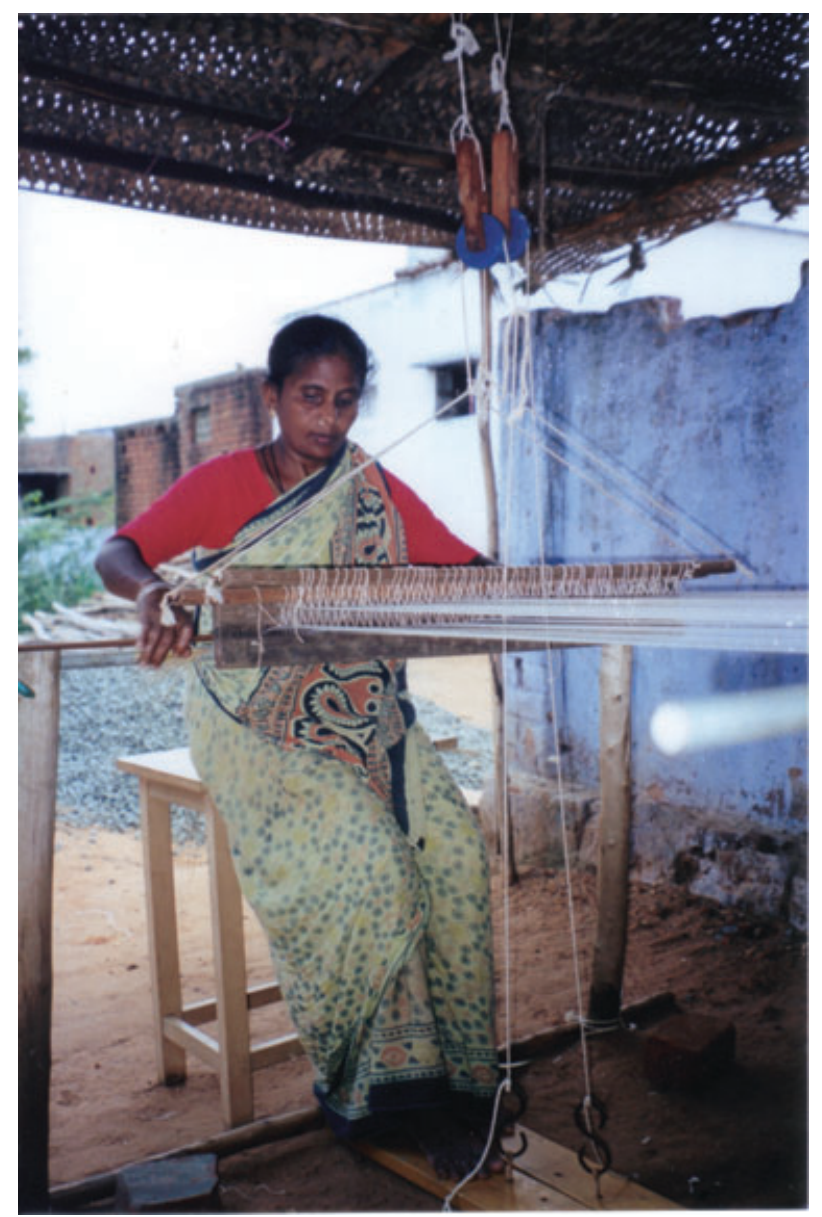

Figure 2. Hassan Fathima sits at the new loom prototype.

Wooden poles form the tripod and define the spatial limits of the loom at either end. A smooth stick inserted through the warp separates it into two interchangeable vertical layers through which weft strands can pass. The kuchali, or 'needle', used to insert weft strands through the warp is also made using a smooth stick with a hole on one end. There is only one component that is difficult to source and relatively expensive: this is the $a c h u$, or reed, which is used to space warp threads evenly and also to tighten the weft. ${ }^{5}$ The new loom has a few more complicated parts: pedals to move the warp up or down; a roller device to roll up and unroll woven sections and unwoven warp, respectively; a frame to lift the warp off the ground; and a high stool or bench. All of these have to be bought or somehow acquired, stored, and maintained. This requires more time, money, and storage space than most weavers are willing to spare. When there is a loom that works, why expend energy and resources on a new loom that, on the face of it, does not confer any significant advantage?

It is not that the weavers are closed to innovations. Indeed, a number have emerged from within the weaving group and have been taken up over the last century or so. All the weavers' own innovations, however, have tended to focus on shortening various 
processes, thereby speeding up the production of mats without significantly changing their quality. This includes laying the warp with shop-bought thread instead of yarn hand-spun in the home.

When it became clear that experienced weavers were not going to 'take to' Lila's loom, she wondered if she should focus her efforts on novice weavers who were not yet habituated to the extant loom. Indeed the site of the trials was crowded with older children and teenagers. And certainly, at least some of the technical problems could be ironed out over time. But I suggest that even those who were excited by the new loom and perhaps willing to use it may not be given the opportunity, resources, or encouragement by other households members to incorporate it into their weaving practice. This is because of a larger underlying issue that, notwithstanding her success in reviving the super-fine mat-weaving industry and her commitment to weaving and bettering work conditions, Lila could not change.

\section{The problem is not with the loom; it is with weaving}

Like Lila, I, too, learned how to weave. But unlike Lila, my learning was not orientated towards problem-solving, nor was it independent. I learned in the spaces in which the Labbais of Pattamadai learned. And like them, I learned that weaving is not highly valued by members of the group, even though it may be praised in public speech acts directed at development practitioners or elites with interests in Pattamadai mats. Notwithstanding Lila's and others' ideas about the national and personal importance of weaving and its relationship to a positive self-identity, few Labbais that I know learned how to weave with the intention of becoming weavers. They did so, or were encouraged to do so, in order to possess a skill that can earn them money.

Money (or, more accurately, the lack of it) causes much anxiety within Pattamadai Labbai households, few of which own agricultural land or have any financial safety nets. In addition to meeting day-to-day expenses, households also have to find money for life-cycle events. These include marriages, where large numbers of people, including every Labbai in the town, need to be feasted; menarche and circumcision celebrations; and funerals. In addition to these are expected and unexpected medical expenses and other expenditures. Borrowing from money-lenders (at high rates of interest) is common practice, as is participation in rolling credit and saving schemes. The above means that almost every Labbai household within Pattamadai requires the economic contribution of adult and teenaged women as well as of men and older boys. What kind of work is chosen for one, or chooses one, depends on the resources available; these include what other people do in the home, the social relationships that can be put to work, financial obligations and the ability to meet them, and, of course, opportunities and constraints.

Certain kinds of work, including securing highly valued jobs in the formal sectors of the economy, require inputs in the way of education beyond secondary-level schooling, which is expensive, especially as it defers the economic contribution of the individual to the household. If a household decides to educate one member at all, it is usually a male who benefits because of the concomitant sacrifices made by others. Other opportunities, including setting up as a trader (of mats, clothing, dry-goods, etc.), require capital, contacts, and specific personal qualities (see Venkatesan 2006). Trading is seen as risky yet worthwhile work. A man can test his powers of persuasion as well as his ability to buy cheap and sell dear. If he does well, he will see rewards. If not, he might have to move on to other kinds of work, including mat-weaving. Simmel's distinction 
between the producer and the trader is strikingly recognizable in Pattamadai: 'In trade, which alone makes possible unlimited combinations, intelligence always finds expansions and new territories, an achievement which is very difficult to achieve for the original producer with his lesser mobility' (Simmel, 1950: 403).

Most men see trading as a far more preferable alternative to the drudgery of weaving. The weaver cannot be mobile. The very nature of his occupation requires his physical presence at the loom, which is firmly fixed in space within the home. Men for whom weaving is the main source of livelihood see themselves as powerless and are likewise perceived by others. Local Labbai mat-traders to whom weavers sell their mats reinforce this. Traders frequently say that weaving is women's work, thereby feminizing all weavers.

Some men migrate for up to three years to the Middle East on labour contracts. Again, they or their households have to put up large sums of money in advance in order to secure jobs and work permits through agents. Men often speak of the jobs they do in the Middle East in dire terms, yet there is an element of excitement in the opportunity to travel and about the possible money to be earned. On their return from the Middle East, these men either make plans to return to the region on new contracts or they remain in Pattamadai, taking up weaving or trading.

Most men, then, move in and out of different occupations, some taking up matweaving during the interim periods. The work of weaving is associated with a lack of enterprise, ability, and opportunity, especially for men who need to weave regularly and not merely occasionally. Because it is based within the home, weaving is seen as work that keeps a man from making his mark in the public sphere. Weaving carries with it a whiff of lack of enterprise, ability, and opportunity.

Women do not venture far from their homes, so making a mark in the public sphere is a lesser issue than it is for men. Once Pattamadai Labbai girls reach menarche they are confined to their homes and immediate environs. From this time until their marriages, girls help around the house with cooking and are actively encouraged to learn household-based skills that can earn money. This is not only so that they can contribute economically; equally important is the concern to give a girl some resources that can hold her in good stead throughout her life. As the mother of a teenage girl said, "We teach girls how to weave and to roll beedis [leaf-cigarettes] as a way of giving them a choice. A boy can always go out and work, but a girl cannot and she may need to have some way of making money after her marriage'.

Marriage alleviates some of the restrictions placed on young women, but they remain spatially bound to their homes and immediate environs. Few take up employment outside the home even if they need to earn money. In homes where women produce mats that are sold to local or other traders, weaving is recognized as crucial to household subsistence. Notwithstanding this, women often deplore the fact that they need to earn money. In the homes of 'people of means' (vasadhi ullavanga), women do not work. This ideal makes many women ambivalent about weaving as well as about other home-based income-generating activities, namely beedi-rolling, which is undertaken for large locally based companies. Certainly, many younger women say they prefer beedi-rolling to weaving because they can take their baskets of tobacco, leaves, and string to their verandas, sit with other girls, and chat as they work.

Payment for beedi-rolling is formally organized with a clear payment structure and schedule. By contrast, payment for mats, especially from local traders, is more informal. As noted above, weavers are necessarily dependent on traders to buy and sell on the 
mats that they make. Local traders do not always pay weavers straightaway for their mats, sometimes withholding payments or partial payments, especially when demand is low. Weavers speak about having to chase up traders day after day for payments due. At other times traders encourage weavers to take advances, thereby binding weavers to them when demand is high. At such times traders or their representatives cycle around the town to visit weavers with mats on their looms and lay claim to the mats, citing previous favours or advances that need repaying. Again, weavers who wish to sell elsewhere or are weaving for their own private purposes feel aggrieved and contrast the behaviour of the traders with that of beedi company representatives.

In conversation, men and women emphasize the hard physical labour involved in weaving. They claim that it causes back pain and stomach problems, it weakens eyesight, and it can affect the reproductive health of young women. And yet, 'what choice do we have?' they ask. 'We need the money.' When there is money available, usually as a result of remittances from the Middle East, people stop weaving, only to take it up when money becomes tight again. It is not that weavers feel no pride or joy in their work. Indeed, sometimes they do. They also always take a great deal of care. If a weaver sees someone else's mat, he or she will comment on the quality of its fabric, its colours and design. But the negative aspects of weaving are emphasized a great deal more.

Making an analogy between weaving and cooking might be useful. Mainly undertaken by women, cooking is a necessary chore, although care is taken in preparing a meal. But there are times, on feast days or special events, when people delight in cooking fine and special dishes. On such occasions both men and women plan and cook the meal and there is much discussion about what to make, how it will be prepared, and by whom. Likewise, there are times when the routine work of making 'yet another mat' becomes charged with interest, enthusiasm, and ambition. For example, one year Khadeeja and her husband, Rahmatullah, who rarely weaves, collaborated on a mat that they wanted to enter into a government-run crafts competition. They spent a great deal of time and energy choosing the design to weave onto the mat (a peacock picked out in colourful silk threads). The mat took them over a month to finish and occasioned both anxiety and excitement, eventually winning an award in the competition. The excitement that weaving generated here, however, is not habitually the case. Like Khadeeja's husband, many men who are capable of weaving do not necessarily want to - at least not all the time.

Marx makes a valuable distinction between work and labour and the very different ways in which each is perceived (see Corsin Jimenez 2003: 15). Work, for Marx, carries use-values. Work is something people enjoy for its own sake; it is its own worth. Labour, on the other hand, is integrated into an economic circuit. It is carried out for money and implies sacrifice and pain of a different order to that implied by work. It is fairly clear that Lila considers weaving as worthwhile work; it is something into which she is willing to invest significant effort. This is not the same for the majority of the Labbais of Pattamadai, for whom weaving is labour most of the time. Only very occasionally does it become worthwhile, usually as an opportunity for gaining public recognition through winning an award. For both male and female Labbai Muslims of Pattamadai, then, while learning how to weave is considered important for subsistence, being a weaver is not necessarily a desirable social status. Weaving here is a means of livelihood bringing in regular sums of money, but simultaneously adversely situating the weaver as powerless, weak, home-bound, and feminized. 


\section{Learning to weave, learning to be a weaver}

I suggested earlier that the spaces and conditions under which one learns a skill like weaving affect what one knows about the skill and its associated ramifications. When I first arrived in Pattamadai and asked people directly about the weaving process and what it involved, I was offered a linear listing of the various processes. Simpson, whose questions about shipbuilding in western India received similar responses, suggests that such a discourse is an instantly recognizable form of explanation, which allows us to visualize/imagine the process - even if we are not equipped with the skills ... ourselves' (2006: 161). Furthermore, these kinds of narratives also serve to 'eradicate conflict, freeze the picture, engage with the expectations of the inquirer ..., and lend themselves too readily to re-description because they already exist in linear form' (2006: 161). It is description not exegesis, and it is certainly not the way one can understand what the Labbais of Pattamadai feel about mat-weaving. In a sense this is a form of description that meets the expectations of development practitioners and interested outsiders, without giving very much away.

When I persisted in asking about weaving, I was told that I should watch, see, try, and thus know what the physical work of weaving is all about. It was often suggested that this is not difficult work (in the sense of complicated or hard to get the hang of) even if it is laborious, tedious, and repetitive. One did not need formal training: one could pick it up by being attentive in spaces where weaving and related processes were going on and then have a go with occasional directed instruction. Indeed, as I found out when I learned how to weave in people's homes and later in a government-run apprenticeship scheme, one could pick up many weaving skills by simply 'being around and trying.'

There are many theories of learning that focus on learning as a social process. The following description of how people learn to weave resonates with Vygotsky's concept of the zone of proximal development, which traces the way in which a child observes, then works alongside an experienced adult, gradually becoming capable of doing everything (Goody 1989: 235). It resonates equally with Ingold's description of the learning of craft skills (2001). He describes how novices are encouraged to pay attention to skilled practitioners, to get a feel for things by trying and to engage in what Dilley (1999; following Bourdieu 1990) terms practical mimesis of more skilled practitioners. The constant and minute adjustments made by the weaver in response to the requirements of the body, the loom, and the raw material, and the working out of problems in the process of weaving, are all testimony to the skilled practice of weaving, mastery over which, as Ingold claims for all craft skills, may be attained only through doing and not by applying prior knowledge to tools and raw materials.

Most people learn the various processes involved in mat-weaving by watching and imitating others. There is no prescribed progression of tasks. Novices try their hand first at whichever task appeals. Several of the tasks go on simultaneously. So, while one mat is on the loom, preparation may be ongoing for the next one(s). As noted above, there is rarely individual ownership over a mat, and different people may be involved in the various processes, from the preparation of the raw materials to the final removal of a mat from a loom.

When a weaving household buys a bundle of korai reeds, every reed has already been split vertically by the seller and dried. The reeds need to be soaked in water so that the pith at the centre rots, and the reed can be split into very fine strands. The korai is soaked for up to a week in the waters of the Kanadiyan canal, which flows through the town. Almost daily, someone from the household is at the canal to bathe or wash 
clothes. While there, they check their bundles and bring them home when the reeds are deemed ready. Once in the house, the bundles are opened and the wet reeds are separated and spread out. Whoever has brought the bundle back does this job. The next task, though, is a specialized one that normally only a more experienced weaver undertakes. Inexperienced persons might also try their hand at it, often sitting with more experienced ones and working alongside them.

A reed is picked up and the rotten pith is scraped away with a sharp knife. The rotten outer husk-like covering is also scraped away. What remains of the reed is held up and split into several fine strands. Depending on the level of skill of the person doing this, and the desired texture of the intended mat, between five and eight strands may be split from a single reed. A less skilled individual might only get two or three strands of even thickness throughout the length. But raw materials are cheap and, unless there is a shortage, the small number of strands is not seen as a significant problem - not initially anyway. All measuring is done by eye and hand, or by what one weaver described as kann nidhanam, the patient estimate of the eye. Once the split reeds are dyed or dried to their natural creamy-golden colour, they are ready for the loom.

The mat-weaving loom occupies a space of approximately 4 feet by 8 feet and is half a foot or so high. It remains rolled up until required, at which point it is tied to four embedded stakes in a corner of the main room of the house, or, if available, on a partially open weaving platform. The cotton warp needs to be laid before weaving can begin. This is a time-consuming task requiring two skilled people with proficiency in tying one particular kind of knot that demands quick and deft fingers. I had great difficulty learning to tie this knot. The elderly woman who showed me began slowly and patiently, and then, expressing increasing frustration, she muttered 'You can read and write and use a computer, but you cannot even tie a knot!' It was evident that she had gone through the same process with younger people in her household. Along with the other girls I discovered that learning how to tie the knot in isolation is a very different thing from actually employing it to ensure that the entire warp is made up throughout of a single continuous thread of even tension. Here, Ingold's distinction between the light experienced hand and the heavy hand of the novice rings true (2001: 24-5). It is not enough to know from watching and imitating, or being taught, or even trying something for oneself a few times. The ability to improvise in relation to the uneven thickness of a thread, the position of the knot, and so on, comes from experience and situated practice. Skill is an outcome not a prerequisite.

Once the loom is set up and the warp is prepared, anyone in the house who wants to weave the weft strands one by one through the warp, and who has arms long enough, does so. This process of inserting korai weft strands through the prepared warp is not difficult, and while a more experienced weaver who is around might give occasional instructions and come to the novice's aid when necessary, by and large the work is carried out in an atmosphere of benign neglect (following Lave \& Wenger 1991: 94).

In the home, then, what we find is a combination of directed learning and picking up skill through watching, imitation, and 'having a go'. We also find selective specialization in different tasks connected to weaving.

While most learning takes place within the home or its environs, occasional opportunities to learn outside the house do present themselves. In 1999, 'Kamran' was appointed by the government as a trainer to teach mat-weaving to students who would each be paid a stipend to attend the six-week-long course. Since I was trying to learn to weave and was interested in how other people learned, I attended Kamran's sessions as 
often as possible. All of the trainees were female; indeed, had there been any young men at the training programme few households would have allowed their girls to attend. ${ }^{6}$

Kamran and a couple of experienced female weavers who were also enrolled as students prepared the looms. Most of the students had watched mothers and others in their homes, and had tried their hand at the various processes involved. Throughout the day the novices sat at the prepared looms and weaved using the korai that they had all assisted in preparing, each according to her individual ability. Kamran and the two experienced weaver 'students' helped with compacting and cut the mats off the loom when done.

Kamran harboured ambitions to be a mat-trader. The way in which he ran the apprenticeship training scheme provided him with mats that he could sell in his shop and in the craft bazaars he attended. He had no need to fear competition from the unmarried female apprentices since, as already mentioned, they were largely restricted to their homes. As far as the female trainees were concerned, their stipend received from the government made the course worthwhile. It also provided them an opportunity to leave their homes for a few hours a day and spend time in congenial company. There was a lot of giggling and chatter.

It became clear through listening and participating in various conversations that in the training space, as in their homes, the girls were learning ways of thinking about weaving. These included thinking about weaving as a means to earn money; as a resource if it became necessary for them to provide for their households after their marriages; as difficult work with meagre returns; as one thing they might do alongside other, more valuable things such as marrying, having children, and so on. Although they were happy to spend time outside their homes with others and receive a stipend, few were enthusiastic about the actual mats they were making or the tasks in which they were engaged. Part of the reason for this was that they knew that learning to weave (even as part of a government scheme) would not lead them to anywhere new. The girls felt certain that weaving would only continue to bind them to the spatial boundaries of their households, whether natal or marital. This was not a problem with weaving per se, but rather the issue was that they were Labbai Muslim girls learning to weave. Girls from other groups might be able to make something of the skill, but not them. In an illuminating conversation between me, a few Labbai girls, and two non-Muslim girls on the course, ${ }^{7}$ the Labbai girls explored the possibilities that might arise for the nonLabbai girls as a result of the course. It was suggested that the non-Muslim girls, who were not restricted in the same ways as their Labbai counterparts, might go on to teach weaving in other towns as part of future governmental initiatives, or they might receive government jobs and travel. Learning to weave could open new worlds for them in ways that the Labbai girls did not feel were available to them.

Lave and Wenger point out in their model of situated peripheral learning that as a skill is learned, so too are the social values and attitudes within which the skill is practised (discussed in Herzfeld 2004: 51). As she weaves, the weaver is (at least some of the time) thinking about other things: keeping a peripheral eye on the children in the house; aware of the smells and requirements of cooking; feeling unease about the damage done by close attention to weaving to an already inflamed eye; aware of the nagging pain in the small of the back; worrying about how to raise money for the next debt re-payment or the marriage of a household member; or wondering whether the payment for the mat will be made promptly or whether the trader will pay only a small part, promising to pay the balance on receipt of yet another mat. And as she is learning how to weave, the novice is also learning gender-based expectations, attitudes to 
weaving, the satisfaction, the pain, the unequal relations of power between weavers and traders, and the belief that one puts in more than one gets out. The novice who weaves or engages in related processes rarely wants to be a weaver any more than do her mother, father, siblings, or contemporaries. She learns that becoming a weaver is a dead end rather than a stepping-stone to more interesting things.

\section{The production and transmission of knowledge}

In his introduction to this special volume, Marchand reflects on a fragment of conversation from his fieldwork: a trainee in a carpentry workshop completes his instructor's sentence about the suitability of oak for a particular project. The interjection directs the conversation into a discussion about the price of oak; the listener/reader is left in doubt as to whether this was what the instructor intended or whether there was something else she might have wanted to say about oak, but did not. Marchand's exploration of the shared production of knowledge suggests that sometimes, despite the best intentions, interlocutors may speak past each other in such a way that they fail to communicate. Lila's sensitive attempt to design an improved loom and its resultant failure has led me, too, to think about shared knowledge production and missed communication. How is it that Lila, who worked with the Pattamadai weavers for several years, learned to weave successfully, and helped revitalize the super-fine mat-weaving industry, nevertheless ended up spending time, energy, and resources on a project that was clearly of little interest and unsuited to its intended beneficiaries? I think that this is partly a result of the very different kinds of knowledge held by Lila and by the Labbais of Pattamadai about weaving and its desirability as an occupation

Lila came to Pattamadai with the very clear idea that the super-fine mat-weaving industry was equally valuable for the weavers as it is for the nation. Craft Enterprises' position was that weavers were giving up weaving because they had no other choice, and the NGO's role was to make that choice available through strategic support and through improving the conditions of work. The Labbais of Pattamadai, however, do not really see weaving as a choice. On the contrary, it is lack of choice that leads many of them to turn to weaving. This is rarely stated explicitly, and certainly never to development practitioners from whom weavers hope to benefit. Rather, in conversations with development practitioners, explicit complaints about weaving are made regarding the exploitative nature of the traders and the need for marketing support. To this extent, the kind of information transmitted is selected and selective. It pertains to areas that development practitioners are expected to address.

Toren (2009) argues strongly that 'we bring to any given encounter with any other our own unique history, that is, the history that we have lived, that makes us who we are, the history out of which we speak, and listen to, and understand others. We cannot help but assimilate others' terms to our own'. As a designer by training, a person with an abiding interest and commitment to craft, and someone with a good sense of the materials and processes, Lila values the Pattamadai mat-weaving industry, the skills of the weavers, and the objects they produce. As far as I could tell from my conversations with her over the years, she was aware that her enthusiasm for weaving surpassed that of the weavers. She certainly hoped that her efforts would make weaving a desirable option for the Labbais of Pattamadai. Indeed, her work in setting up a reliable and efficient system wherein the NGO would buy mats from weavers, making prompt payments and then selling on the mats in urban areas, is testimony to her recognition that weaving is first and foremost a matter of livelihood. Her attempt to improve the 
loom likewise came from her taking seriously weavers' grumblings (rarely couched as explicit complaints) about bodily troubles and discomfort caused by weaving.

Lila's loom is proof of her problem-solving capacities, but as far as the weavers were concerned, it was the wrong problem: it is not the loom that makes weaving laborious and painful; the problem is having to weave in the first place. In a sense, one might say that Lila took on board what was explicitly stated by weavers as the problems with weaving and she sought to resolve them. But the explicit complaints masked underlying implicitly held knowledge about weaving as undervalued labour. This was not something that could be explicitly tackled - nebulous and embedded as it is in the entirety of Pattamadai Labbai life. Lila's knowledge of weaving as worthwhile work in and of itself was something about which even the weavers she worked most closely with remained unconvinced.

A trader who was scornful of the entire project of improving the loom, while also curious about it, supplied his own reasons for its failure. 'This is women's work', he said, though being fully aware that some male weavers were participating in the trial, 'and women are not good at picking up new things'. I read his statement as one that positions weaving firmly in the sphere of women - weak, defenceless people who have few choices but make the most of what they have without seeking to improve their lot. What he was saying was that people who could successfully work with new ideas, incorporate new technologies, take advantage of new opportunities, would not be weavers. This, too, is common knowledge within Pattamadai and the reason why even those who can weave do not want to be weavers.

\section{Conclusion}

I suggested early on that Lila and I were similar in some ways. We were both interested in Pattamadai mat-weaving and both lived in Pattamadai among the weavers with whom we worked. The difference between us, however, is that, as a development practitioner, Lila knew what she was doing in Pattamadai in terms of developing the mat-weaving industry. Once she had settled down to her work, Lila's encounters with weavers were by and large directed and focused on production times, costs, training, sales, and designs. They were active and practical conversations about plans, problems, and possible solutions.

As the anthropologist, I did not know exactly what I was doing in Pattamadai (see Herzfeld 2007). I was around, interested, learning to weave or to cook, asking questions that sometimes led somewhere specific but most of the time opened up unanticipated conversations. Without being fully aware, I perhaps always knew about the low worth placed on weaving in Pattamadai. The lukewarm response to, and ultimate failure of, Lila's thoughtful attempt to modify the loom brought several conversations and insights together more clearly not only for me, but also for Lila, as we discussed in detail the project, its underpinnings, aims, and assumptions. Nevertheless, differences in what we conceived as our roles in Pattamadai persisted. When I finished my doctoral thesis and gave it to Lila to read, we had a telling conversation. She said she agreed with large parts of my analysis and understanding of the mat-weaving industry, but she had a question: what was I going to do now? Surprised, I said, 'Nothing. I guess people will read my work and it might inform their work'. Unsurprisingly this response did not satisfy her. Indeed, how could it, pointing as it does to the gulf between knowing for the sake of knowing and knowing in order to act?

Anthropologists have long been critical about 'development' (e.g. Escobar 1995; Ferguson 1994; Grillo \& Stirrat 1997; Hobart 1993; however see Venkatesan \& Yarrow 2010). As Herzfeld (2007) puts it, we are on the side of the marginalized - the same 
people whom development professionals seek to 'help'. The suspicion directed at development (and, by extension, development professionals) is often in diametric contrast to the value anthropologists place on 'local knowledge' and the attachment of the people with whom we work to their 'traditional practices', including artisanal or craft work. Indeed, anthropological studies of skill acquisition within artisanal groups have frequently focused on the kinds of skills that are valued both socially and by the individuals seeking to acquire them (an exception is Herzfeld 2004). This has given a particular flavour to anthropological understandings of artisanal work, and the value accorded to it - its world-creating abilities (Brouwer 1996), its rich symbolic content (e.g. Guss 1990) - analogically and to notions of embodied skill as doing rather than knowing (Ingold 2001). By contrast, this paper has focused on a sensitive and thoughtful intervention made by a development practitioner among a group of artisanal producers who are themselves ambivalent about what they describe as their traditional occupation of mat-weaving. In doing so, I sought to explore the embodied and historicized production of knowledge by different kinds of person: the weavers of Pattamadai, a development professional, and, to a certain extent, an anthropologist.

I have argued in this paper that when people learn craft skills in a socially embedded setting, they also learn how to think about the work this enskilment will enable them to do. The anthropology of learning in such cases has to incorporate the anthropology of work. When someone from a different social setting learns the same skill, they may acquire mastery over it but may not know what the skill entails for those who need to practise it.

A final word about knowledge. People in Pattamadaiknow that development initiatives come and go, even if individual development practitioners are completely committed to working with them. This is something they are prepared for. A development initiative may be beneficial while it lasts. When it is gone, it is business as usual (see Venkatesan 2006). Craft Enterprises no longer exists. Its funding ceased in 2001 and with it went the regular and stable market that it had created and nurtured. Although Lila has stopped working on modifying the loom, she continues to work with some weavers, designing and marketing mats. We remain in contact and she remains concerned about helping the mat-weaving industry. Most of the mat-weavers who worked with Crafts Enterprises have perforce had to return to the local traders who continue to buy mats when they need them and delay payments. The Labbais of Pattamadai continue to move in and out of weaving their high-quality mats as opportunities and constraints dictate. And they continue to know that weaving is not a choice, but a lack of choice.

\section{NOTES}

I am grateful to the people of Pattamadai for their friendship and for allowing me access to their homes and looms. I am also grateful to 'Lila' for years of conversations. Trevor Marchand's comments have been invaluable in thinking through this paper. Other contributors to this special issue also provided valuable comments. Thanks to Christina Toren for permitting me to cite her unpublished paper. I am also thankful for feedback received at the Transmission of knowledge seminar series at SOAS and the Social Anthropology seminar at Manchester where versions of this paper were presented. Any problems that remain are, of course, my responsibility.

${ }^{1}$ I began my doctoral fieldwork in Pattamadai in 1997, and each year throughout my Ph.D. and since completion I have spent several months there.

${ }^{2}$ Two qualities of mats are woven in Pattamadai. Medium-quality or 'fine mats' are of 50 count while high-quality or 'super-fine' mats are of 100-40 count, meaning every 9 inches of warp is made up of between 100 and 140 threads. Super-fine mats take thrice as long to make as fine mats and are consequently proportionately more expensive to buy from weavers. 


\section{S174 SOUMHYA VENKATESAN}

${ }^{3}$ The number grew to eight by 1998 though dropped to six by 2000 as one weaver stopped working with the NGO and another gave up weaving altogether.

${ }^{4}$ The prices were established through consultation and discussion and were almost double what local traders would pay for the same mats. It must be remembered that Craft Enterprises, selling in more up-market spaces than local traders could access, could also market the mats for far higher prices than the Labbai traders of Pattamadai.

${ }^{5}$ The super-fine mat-weaving $a c h u$, like the cloth-weaving $a c h u$, has a wooden frame and very fine metal 'eyes'. Craft Enterprises located a maker of achu for sari-weavers and commissioned him to make matweaving $a c h u$. This was successful, and several weavers bought new achu to replace their old and damaged ones (see Venkatesan 2009a: chap. 9 for more details).

${ }^{6}$ As a middle-aged married man, Kamran was not seen as a cause for concern. Further, the way in which the idiom of kinship is mobilized in Pattamadai means that most teenagers at the training programme refer to him as either a paternal or maternal 'uncle' (mama, chacha, periappa, etc.).

${ }^{7}$ Both of these girls were enrolled in accordance with the government ruling that members of scheduled and/or backward castes (SC/BC) be represented within the training scheme. Neither went on to weave.

\section{REFERENCES}

Bourdieu, P. 1990. The logic of practice (trans. R. Nice). Stanford: Univesity Press.

Brouwer. J. 1996. Makers of the world: caste, craft and mind. Delhi: Oxford University Press.

Corsin Jimenez, A. 2003. Working out personhood: notes on 'labour' and its anthropology. Anthropology Today 19: 5, 14-17.

Dilley, R. 1999. Ways of knowing, forms of power. Cultural Dynamics 11, 33-55.

EscoBAR, A. 1995. Encountering development: the making and unmaking of the Third World. Princeton: University Press.

Ferguson, J. 1994. The anti-politics machine: 'development', depoliticization, and bureaucratic power in Lesotho. Minneapolis: University of Minnesota Press.

Goody, E.N. 1989. Learning, apprenticeship and the division of labour. In Apprenticeship: from theory to method and back again (ed.) M.W. Coy, 233-56. Albany, N.Y.: SUNY Press.

Grillo, R.D. \& R.L. Stirrat (eds) 1997. Discourses of development: anthropological perspectives. Oxford: Berg.

Guss, D.M. 1990. To weave and sing: art symbol and narrative in the South American rainforest. Berkeley: University of California Press.

Herzfeld, M. 2004. The body impolitic: artisans and artifice in the global hierarchy of value. Chicago: University Press.

2007. Deskilling, 'dumbing down' and the auditing of knowledge in the practical mastery of artisans and academics: an ethnographer's response to a global problem. In Ways of knowing: new approaches in the anthropology of experience and learning (ed.) M. Harris, 91-112. Oxford: Berghahn.

Hobart, M. 1993. An anthropological critique of development: the growth of ignorance. London: Routledge.

INGOLD, T. 2001. Beyond art and technology: the anthropology of skill. In Anthropological perspectives on technology (ed.) M.B. Schiffer, 17-32. Albuquerque: University of New Mexico Press.

Lave, J. \& E. Wenger 1991. Situated learning: legitimate peripheral participation. Cambridge: University Press.

Nambiar, P K. 1964. Fine mats of Pattamadai, vol. IX: Madras, part VII-A-IV: Handicrafts and artisans of Madras State, Census of India 1961. Madras: Census of India.

Pate, H.R. 1917. Gazetteer of the Tinnelvelly district, vol. 1: Madras District Gazetteers. Madras: Government Press.

RAO, N. 1929. Report on survey of cottage industries. Madras: Government Press.

Sennett, R. 2008. The craftsman. London: Penguin.

Simmel, G. 1950. The stranger. In The sociology of Georg Simmel (ed.) K. Wolff, 402-8. New York: Free Press. Simpson, E. 2006. Apprenticeship in western India. Journal of the Royal Anthropological Institute (N.S.) 12 $151-71$.

Toren, C. 2009. Imagining the world that warrants our imagination - the revelation of ontogeny. Unpublished paper presented at the Materializing the subject conference, Manchester, February.

Venkatesan, S. 2006. Shifting balances in a 'craft community': the mat-weavers of Pattamadai, South India. Contributions to Indian Sociology (N.S.) 40, 63-89.

2009a. Craft matters: artisans, 'development' and the Indian nation. Delhi: Orient Blackswan. $2009 \mathrm{~b}$. Rethinking agency: persons and things in the heterotopia of 'traditional Indian craft'. Journal of the Royal Anthropological Institute (N.S.) 15, 78-95. 
\& T. YARrow (eds) 2010. Differentiating development: beyond an anthropology of critique. Manuscript submitted for publication.

Wallman, S. 1979. Introduction. In Social anthropology of work (ed.) S. Wallman, 1-24. London: Academic Press.

WILK, R.R. 2001. Towards an anthropology of needs. In Anthropological perspectives on technology (ed.) M.B. Schiffer, 107-22. Albuquerque: University of New Mexico Press.

\title{
Apprendre à tisser, tisser pour apprendre ... quoi ?
}

\begin{abstract}
Résumé
Le présent article confronte l'anthropologie de l'apprentissage à l'anthropologie du travail en révélant les relations entre les processus d'acquisition d'une compétence et la connaissance de cette compétence, de ses possibilités et de ses ramifications. Le sujet ethnographique de l'article concerne les tisserands de tapis Labbai de la ville de Pattamadai, dans le Sud de l'Inde, qui ont une attitude ambivalente vis-à-vis de leur statut de tisserands. L'auteur met en regard cette ambivalence et l'intérêt éveillé par le tissage chez un intervenant en développement qui cherchait à promouvoir l'artisanat du tissage et avait même appris à tisser. La même compétence est approchée différemment par différentes sortes de personnes : celles-ci voient et comprennent des choses différentes. L'apprentissage et la connaissance ne peuvent pas être facilement dissociés. En se concentrant sur les différents buts et modes de l'apprentissage, sur la production sociale de connaissance et sur des cas de communication bien et mal menée, l'article explore la production incorporée et historicisée de connaissances par différentes sortes de personnes : les tisserands, le professionnel du développement et, dans une certaine mesure, l'anthropologue.
\end{abstract}

Soumhya Venkatesan is a Lecturer in Social Anthropology at the University of Manchester. Based on fieldwork with Muslim mat-weavers in South India and carpet-weavers in Bukhara, her research focuses on materiality and the relationship between people and things, and explores issues of embodiment and the transmission of skills. Her present research on Indian potters and sculptors of venerated idols considers the relation between makers and objects. She is currently preparing a book manuscript based on her doctoral research.

Social Anthropology, University of Manchester, Arthur Lewis Building, Manchester M13 9PL, UK. Soumhya.Venkatesan@manchester.ac.uk 